\title{
The natural sweetener metabolite steviol inhibits the proliferation of human osteosarcoma U2OS cell line
}

\author{
JUN-MING CHEN ${ }^{1}$, JUE ZHANG ${ }^{2}$, YONG-MEI XIA ${ }^{1}$, XIAO-XIA WANG ${ }^{1}$ and JIAN LI $^{2}$ \\ ${ }^{1}$ State Key Laboratory of Food Science and Technology, School of Chemical and Materials Engineering, \\ Jiangnan University, Wuxi, Jiangsu 214122; ${ }^{2}$ Key Laboratory of Nuclear Medicine of Ministry of Health, \\ Jiangsu Institute of Nuclear Medicine, Wuxi, Jiangsu 214063, P.R. China
}

Received May 17, 2016; Accepted December 13, 2017

DOI: $10.3892 / \mathrm{ol} .2018 .7962$

\begin{abstract}
Steviol is the colonic metabolite of the natural sweetener steviol glycosides. It does not diffuse to the blood and the half maximal inhibitory concentration of steviol is longer compared with that of current chemotherapy agents, including 5-fluorouracil and doxorubicin. The present study demonstrated that steviol inhibits the proliferation of the human osteosarcoma U2OS cell line in a dose- and time-dependent manner, and that the inhibition rate is comparative with that of doxorubicin and 5-fluorouracil. The mechanism of this anticancer activity is also investigated. The results indicated that steviol inhibits U2OS cells through inducing G1 phase cell cycle arrest, downregulating the ability of colony formation via a mitochondrial apoptotic pathway, which was indicated by an increase of the $\mathrm{Bax} / \mathrm{Bcl}-2$ ratio and activation of cyclin-dependent kinase inhibitor 1, tumor protein 53 and cyclin-dependent kinase; whereas a Survivin and Caspase 3 -independent mechanism was involved. Considering that steviol appears minimally in the plasma during metabolism, and possesses a median lethal dose of 100 -fold greater compared with that of 5-fluorouracil, it may become a potential chemotherapy agent.
\end{abstract}

\section{Introduction}

Steviol glycosides, a family of popular natural non-nutritive sweeteners from leaves of Stevia rebaudiana bertoni, are metabolized in human colon by colon bacteria. The colonic metabolite of the primary steviol glycosides, including rebaudioside A and stevioside, is steviol. In the colon, portions of this steviol is absorbed and then undergoes glucuronidation

Correspondence to: Professor Yong-Mei Xia, State Key Laboratory of Food Science and Technology, School of Chemical and Materials Engineering, Jiangnan University, 1800 Lihu Avenue, Wuxi, Jiangsu 214122, P.R. China

E-mail: ymxia@jiangnan.edu.cn

Key words: steviol, osteosarcoma, U2OS, steviol glycoside, apoptosis in the liver, while the remaining is identified in feces $(1,2)$. At present, a few of studies have been reported about the cytotoxicity of steviol on human resource cells.

Steviol exhibits a kaurene diterpenoid structure, similar to that of gibberellin (3). Its rearrangement product isosteviol and steviol itself have been used as starting reagents for synthetic medicines (4). The acceptable daily intake of steviol is $4 \mathrm{mg} / \mathrm{kg}$ body weight/day (5) and its median lethal dose $\left(\mathrm{LD}_{50}\right)$ value is $15 \mathrm{~g} / \mathrm{kg}$ body weight in rats and mice, irrespective of the gender (3). During the metabolism of steviol or steviol glycosides, steviol is not detectable in blood, and half maximal inhibitory concentration $\left(\mathrm{IC}_{50}\right)$ value of steviol is much higher than that of current chemotherapy agents such as 5-fluorouracil (5-FU) and doxorubicin (6). Therefore, if steviol could efficiently inhibit cancer cells with clear mechanism, it could be expected as a chemotherapy agent applied in large doses.

High-dose chemotherapy and chemoresistance are the typical features of osteosarcoma treatment, which is a primary malignant bone cancer with high morbidity $(7,8)$. Patients with metastasis exhibit a 5-year survival rate of only $20 \%(9,10)$. Efficient treatment of osteosarcomas requires systemic chemotherapy prior and subsequent to surgery (11). The majority of chemotherapy regimens applied in OS are based on the following drugs: High-dose methotrexate with leucovorin rescue (12), doxorubicin (Adriamycin $\left.{ }^{\circledR}, \mathrm{ADM}\right)$, cisplatin, and ifosfamide (13). These regimens are associated with marked short- and long-term collateral toxic effects (14), including acute alopecia, myelosuppression, mucositis and nausea (15). In addition, rare ADM-regimen cases of toxic mortalities caused by early or late cardiac failure have been identified, which were due to ADM toxicity and sepsis following febrile neutropenia (16).

Therefore, many efforts have been made to develop novel drugs to increase the number of options for chemotherapy in OS, such as: Rapamycin (17); ampelopsin (18); JQ1 (a BET protein inhibitor) in combination with rapamycin (19); and few other small molecules (20). However, only a small number of studies have been conducted on the use of natural medicines such as evodiamine (21), riccardin D (22) and piperine (8).

The anticancer activity of steviol has not been well examined. Boonkaewwan and Burodom (22) suggested that unpurified steviol did not present cytotoxicity on Caco-2 
cells at $0.1-100 \mu \mathrm{mol} / 1$, but it suppressed lipopolysaccharide (LPS)-mediated tumor necrosis factor- $\alpha$, interleukin (IL)- $1 \beta$ and IL-6 release, and attenuated the production of LPS-induced pro-inflammatory cytokines. However, higher steviol dosage (200-800 $\mu \mathrm{mol} / \mathrm{l})$ decreased cell viability of T84, Caco-2 and HT29 cells (23). Steviol also inhibited renal cyst growth in a mouse model of polycystic kidney disease (24). A two-stage carcinogenesis model on mouse skin demonstrated that steviol markedly inhibited the promotion and initiation stages of lymphoblastoid cells (25). These results suggest that steviol may be a potential chemotherapy agent for cancer treatment.

At present, with the exception of some aforementioned studies investigated the inhibition of the proliferation of cancer cells by steviol, including lymphoblastoid cells (25), none have explored its possible molecular mechanisms. Our preliminary study indicated an anti-cancer activity of steviol on human osteosarcoma U2OS cells (data not shown). Therefore, the present study focused on the in vitro anti-proliferative effects of steviol on human osteosarcoma U2OS cells and the potential molecular mechanisms involved.

\section{Materials and methods}

Materials and chemicals. Steviol (Sigma-Aldrich, Shanghai, China $99 \%$ purity as determined by high performance liquid chromatography); doxorubicin (AMD) was purchased from Shanghai Aladdin Bio-Chem Technology Co., Ltd. (Shanghai, China). 5-FU (biological-grade reagent, BR), dimethyl sulfoxide (DMSO, BR), $\mathrm{Na}_{2} \mathrm{CO}_{3}, \mathrm{NaHCO}_{3}, \mathrm{NaCl}$, $\mathrm{KCl}, \mathrm{Na}_{2} \mathrm{HPO}_{4} \cdot 12 \mathrm{H}_{2} \mathrm{O}, \mathrm{NaH}_{2} \mathrm{PO}_{4} \cdot 2 \mathrm{H}_{2} \mathrm{O}$, EDTA disodium, SDS, glycocoll, bromoxylenol blue, ammonium persulphate, tris (hydroxymethyl) methyl aminomethane (BR), Ponceau (BR), N,N,N,N-tetramethylethylenediamine (TEMED, 99\%), xylene brilliant cyanin G (BS, G250), and phenylmethylsulfonyl fluoride (PMSF, 99\%) were purchased from Sinopharm Chemical Reagent Co., Ltd., (Shanghai, China). Trypsin-EDTA solution, propidium iodide (PI), Triton X-100, endonuclease (RNase A), 3-(4,5-dimethylthiazol-2-yl)-2,5-diphenyltetrazolium bromide (MTT), penicillin-streptomycin solution (100X), BeyoECL Plus, polyvinylidene fluoride, radioimmunoprecipitation assay (RIPA) lysis buffer and 5,5',6,6'-tetrachloro-1,1',3,3'-tetraethyl-imidacarbocyanine iodide (JC-1) were purchased from Beyotime Institute of Biotechnology Co., Ltd. (Shanghai, China). Dulbecco's modified Eagle's medium (DMEM) and fetal bovine serum (FBS) were purchased from Gibco; Thermo Fisher Scientific, Inc. (Waltham, MA, USA). All antibodies were purchased from Cell Signaling Technologies, Inc. (Danvers, MA, USA): Primary antibodies against cyclin-dependent kinase inhibitor 1 rabbit mAb (p21, $21 \mathrm{kDa}$; cat. no. 2947S; 1:1,000 dilution), tumor protein 53 rabbit mAb (p53, $53 \mathrm{kDa}$; cat. no. 2527S; 1:1,000 dilution), Cyclin D1 rabbit mAb (36 kDa; cat. no. 2978T; 1:1,000 dilution), Cyclin E rabbit mAb (48 kDa; cat. no. 20808S; 1:1,000 dilution), cyclin-dependent kinase 2 (CDK2; cat. no. 78B2) rabbit mAb (33 kDa; cat. no. 2546S; 1:1,000 dilution), B-cell lymphoma 2 (Bcl-2) mouse mAb (26 kDa; cat. no. 15071S; 1:1,000 dilution), Bcl-2 X associated protein (Bax) rabbit mAb (20 kDa; cat. no. 5023S; 1:1,000 dilution), Caspase 3 rabbit mAb (35 kDa; cat. no. 9665S; 1:1,000 dilution), Survivin rabbit mAb
(16 kDa,; cat. no. 2808S; 1:1,000 dilution), $\beta$-Actin rabbit mAb (45 kDa; cat. no. 4970S; 1:1,000 dilution) and horseradish peroxidase-conjugated secondary antibodies (anti-rabbit IgG, HRP-linked antibody; cat. no. 7074; anti-mouse IgG, HRP-linked antibody; cat. no. 7076). All other reagents were of analytical grade and used as purchased, unless otherwise stated.

Cell culture. The human osteosarcoma U2OS cell line was purchased from Shanghai Institute of Biochemistry and Cell Biology, Chinese Academy of Science (Shanghai, China). Cells were maintained in DMEM supplemented with $10 \%$ FBS, $1 \%$ glutamine $(200 \mathrm{mmol} / \mathrm{l})$, penicillin $(100 \mathrm{IU} / \mathrm{ml})$, and streptomycin $(100 \mathrm{mg} / \mathrm{l})$ in a humidified $5 \% \mathrm{CO}_{2}$ atmosphere at $37^{\circ} \mathrm{C}$ prior to use.

MTT assay on cell proliferation. The effect of steviol on carcinoma cell proliferation was evaluated with an MTT assay $(26,27)$. The cells in the logarithmic growth phase were digested with $0.25 \%$ trypsin and adjusted to 5,000 cells/well using DMEM complete medium. Prior to the steviol treatment, $100 \mu \mathrm{l}$ cell suspension was pipetted into each well in 96-well plates and cultured for $24 \mathrm{~h}$ at $37^{\circ} \mathrm{C}$ in $5 \% \mathrm{CO}_{2}$. Subsequently, cells were incubated with steviol at $37^{\circ} \mathrm{C}$ in $5 \% \mathrm{CO}_{2}$ for $48 \mathrm{~h}$. The culture medium was then removed and $100 \mu \mathrm{l}$ MTT reagent $(0.5 \mathrm{mg} / \mathrm{ml}$ in culture medium) was added. Following an additional $4 \mathrm{~h}$ of incubation, the MTT/medium was removed and $150 \mu \mathrm{l}$ of DMSO was added to dissolve the formazan crystals. Absorbance of the solution was recorded at $570 \mathrm{~nm}$ to calculate the inhibition rate on cell growth. Chemotherapy agents 5-FU and ADM were employed as positive controls. Cells without drug treatment were used as the control. All measurements were performed in triplicate. The inhibition rate was calculated as following:

$$
\text { inhibition rate }(\%)=\frac{A_{570} \text { of control }-A_{570} \text { of sample }}{A_{570} \text { of control }} \times 100
$$

Colony formation assay. U2OS cells were plated in 6-well plates at a density of 1,000/well. Following $12 \mathrm{~h}$ of incubation, the cells were treated with $0,5,10$ and $20 \mu \mathrm{g} / \mathrm{ml}$ of steviol. Following 14 days of incubation, the media were removed, and the cells were washed three times with PBS prior to the addition of $1 \mathrm{ml}$ methanol to each well for $15 \mathrm{~min}$ at $37^{\circ} \mathrm{C}$. The cells were then washed three times with PBS for about 1 min each and incubated with $0.1 \%$ crystal violet for $10 \mathrm{~min}$ at $37^{\circ} \mathrm{C}$. Finally, the plates were washed five times and cell colonies were counted with microscopy.

Cell cycle analysis. U2OS cells were plated at $2 \times 10^{5} /$ well in 6 -well plates and treated with steviol $(0,50,100$ and $200 \mu \mathrm{g} / \mathrm{ml})$. After $48 \mathrm{~h}$, the cells were then harvested with trypsin, washed three times for $1 \mathrm{~min}$ each, resuspended in cold PBS and fixed in $4^{\circ} \mathrm{C} 70 \%$ ethanol for $4 \mathrm{~h}$, and storage at $-20^{\circ} \mathrm{C}$ overnight. Next, the cells were washed three times for $1 \mathrm{~min}$ each and resuspended in PBS containing $40 \mu \mathrm{g} / \mathrm{ml}$ PI and $0.1 \mathrm{mg} / \mathrm{ml}$ RNase (cat. no. C1052; Beyotime Institute of Biotechnology Co., Ltd), and then incubated for $30 \mathrm{~min}$ at room temperature. PI-stained cells were analyzed using a flow cytometer and ModFit LT 5.0 software (Verity Software House, Inc., Topsham, ME, USA). 

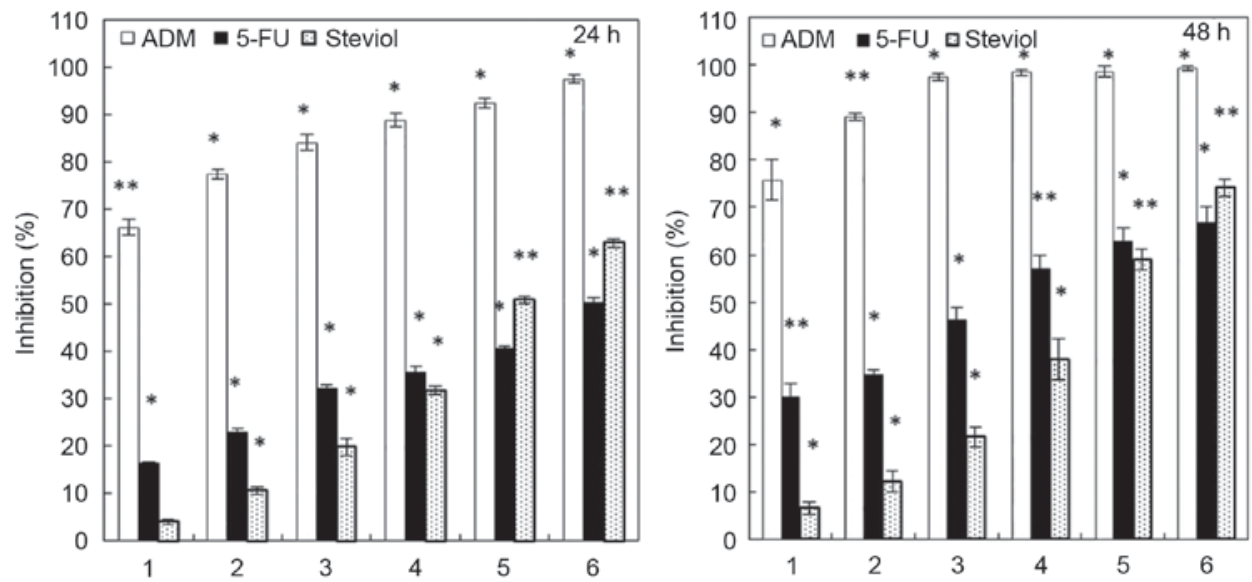

Figure 1. Inhibition of U2OS proliferation by steviol at 24 and $48 \mathrm{~h}$. Numbers 1-6 represent the sample concentrations ( $\mu \mathrm{g} / \mathrm{ml})$ : ADM: 1, 2, 5, 10, 20, 25; 5-FU and steviol: $25,50,100,150,200,250$, respectively. ${ }^{*} \mathrm{P}<0.05$ and ${ }^{* *} \mathrm{P}<0.01$ vs. untreated cells.

A

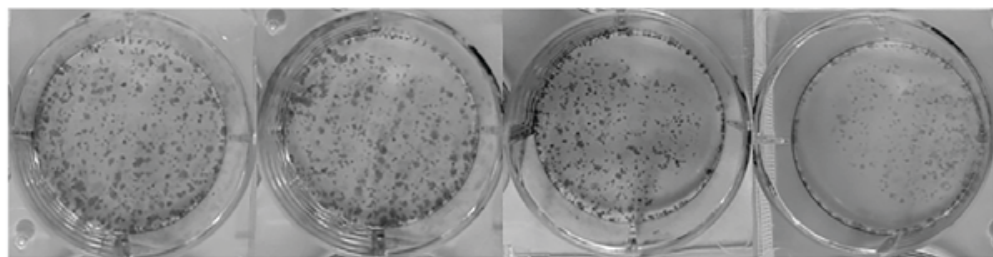

$0 \mu \mathrm{g} / \mathrm{ml}$ $5 \mu \mathrm{g} / \mathrm{ml}$ $10 \mu \mathrm{g} / \mathrm{ml}$ $20 \mu \mathrm{g} / \mathrm{ml}$

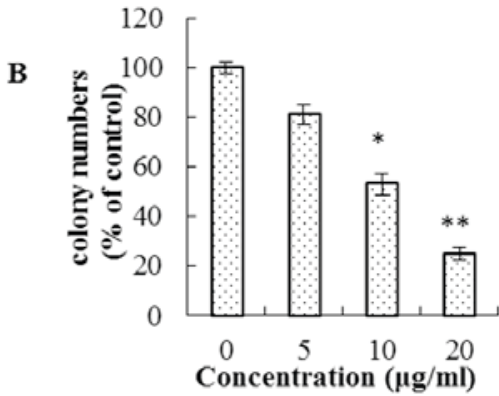

Figure 2. Steviol inhibits colony formation in U2OS cells. (A) Cells treated with steviol for 14 days. (B) Colony numbers of $\mathrm{U} 2 \mathrm{OS}$ cells. ${ }^{*} \mathrm{P}<0.05$ and ${ }^{* *} \mathrm{P}<0.01$ vs. untreated cells.
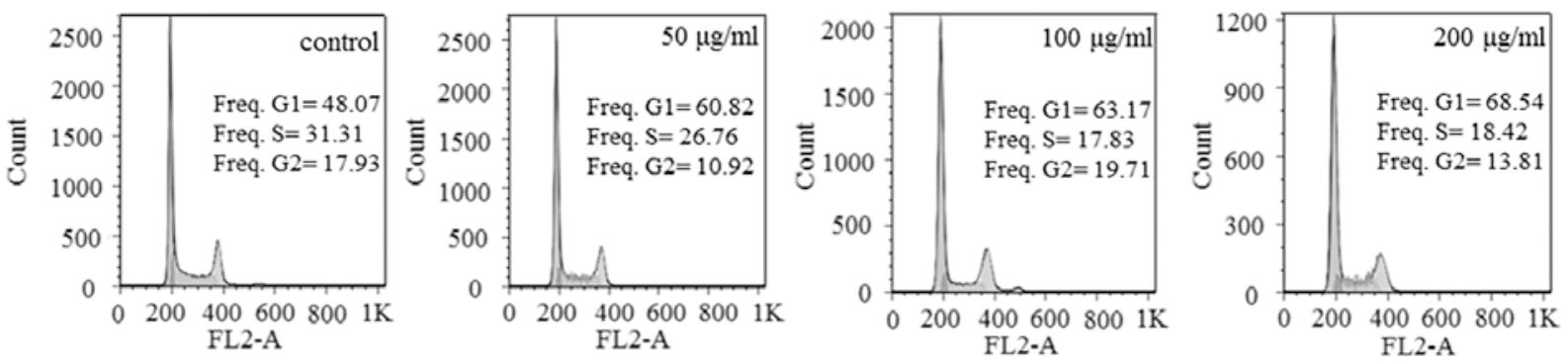

Figure 3. Effect of steviol on the cell cycle distribution of U2OS cells. Cell count of U2OS cells at different points of the cell cycle when treated with increasing concentrations of steviol. FL2-A, fluorescence area.

Mitochondrialmembrane potential detection and Hoechst 33342 staining assay. Mitochondrial membrane potential detection was conducted with a JC-1 assay (cat. no. C2006; Beyotime Institute of Biotechnology Co., Ltd). Briefly, following steviol treatment $\left(0,50,100\right.$ and $200 \mu \mathrm{g} / \mathrm{ml}$ for $48 \mathrm{~h}$ at $\left.37^{\circ} \mathrm{C}\right)$, cells were cultured in 24-well plates and incubated with $\mathrm{JC}-1$ staining solution (5 $\mu \mathrm{g} / \mathrm{ml}$; cat. no. C2006; Beyotime Institute of Biotechnology Co., Ltd.) for $20 \mathrm{~min}$ at $37^{\circ} \mathrm{C}$. Cells were then rinsed twice with JC-1 staining buffer. Cells on chamber slides were scanned with a fluorescence microscope (magnification, $\mathrm{x} 400$ ).

Hoechst 33342 staining assay. U2OS cells were seeded onto chamber slides in 6 -well plates at a density of $1 \times 10^{5}$ cells/well for $24 \mathrm{~h}$ of incubation in DMEM supplemented with $10 \%$ of FBS and incubated at $37^{\circ} \mathrm{C}$ in $5 \% \mathrm{CO}_{2}$. The medium was removed and replaced with medium containing steviol for $24 \mathrm{~h}$ at $37^{\circ} \mathrm{C}$ in $5 \% \mathrm{CO}_{2}$. Subsequent to the removal of the medium, the cells were washed three times for $2 \mathrm{~min}$ each with ice-cold PBS and then fixed with formalin $(4 \%, \mathrm{w} / \mathrm{v})$ for $15 \mathrm{~min}$ at $37^{\circ} \mathrm{C}$. Cell nuclei were counterstained with Hoechst $33342(10 \mathrm{mg} / \mathrm{ml}$ in PBS) for $10 \mathrm{~min}$ at $37^{\circ} \mathrm{C}$, and then observed and imaged using fluorescence microscopy (magnification, $\mathrm{x} 400$ ).

Determination of apoptotic percentage in cells. Apoptotic percentage in cells was tested using Annexin V-fluorescein isothiocyanate (FITC)/PI double-labeled flow cytometry. U2OS cells were plated at a density of $2 \times 10^{5} /$ well in a 6 -well flask and exposed to $0,50,100$ and $200 \mu \mathrm{g} / \mathrm{ml}$ of steviol for $24 \mathrm{~h}$ at $37^{\circ} \mathrm{C}$ 
Table I. Regulation of steviol on cell cycle progression of U2OS cells.

\begin{tabular}{lccc}
\hline & \multicolumn{3}{c}{ Cell cycle stage } \\
\cline { 2 - 4 } Dosage $(\mu \mathrm{g} / \mathrm{ml})$ & $\mathrm{G} 1(\%)$ & $\mathrm{S}(\%)$ & $\mathrm{G} 2(\%)$ \\
\hline Control & 48.07 & 31.31 & 17.93 \\
Steviol & & & \\
50 & 60.82 & 26.76 & 10.92 \\
100 & 63.17 & 17.83 & 19.71 \\
200 & 68.54 & 18.42 & 13.81 \\
\hline
\end{tabular}

in $5 \% \mathrm{CO}_{2}$. Followed by $24 \mathrm{~h}$ of incubation at $37^{\circ} \mathrm{C}$, cells of $2 \times 10^{6} /$ well were collected, centrifuged $(1,000 \mathrm{x}$ g for $3 \mathrm{~min}$ at room temperature), and resuspended in $100 \mu$ l Annexin blinding buffer, then stained with Annexin V-FITC (5 $\mu \mathrm{l})$ and propidium iodide (PI; $1 \mu \mathrm{l}$ ) for $15 \mathrm{~min}$ of incubation at room temperature. Cells were detected with a FACS Calibur flow cytometer subsequent to the addition of $400 \mu 1$ Annexin-blinding buffer.

Western blot analysis. Steviol-treated cells were digested with $0.25 \%$ trypsin and $0.2 \%$ EDTA, washed with cold $\left(4^{\circ} \mathrm{C}\right) \mathrm{PBS}$ three times for $1 \mathrm{~min}$ each, suspended in ice-cold RIPA lysis buffer containing $1 \mathrm{mM}$ PMSF and incubated on ice for $30 \mathrm{~min}$. The suspension was then centrifuged at $12,000 \mathrm{x} g$ for $5 \mathrm{~min}$ at $4^{\circ} \mathrm{C}$. The protein concentration of lysates was measured with the Bradford method. Equivalent amounts of protein $(40 \mu \mathrm{g})$ were separated using a $10 \%$ gel and SDS-PAGE and then transferred to a polyvinylidene difluoride membrane. Membranes were blocked for $1 \mathrm{~h}$ at room temperature using TBST containing $5 \% \mathrm{w} / \mathrm{v}$ non-fat milk, and probed with primary antibodies overnight at $4^{\circ} \mathrm{C}$ following washing three times for 5 min each. The membranes were incubated with secondary antibody for $1 \mathrm{~h}$ at room temperature. Protein bands were detected using the ChemiDoc MP imaging system (Image Lab 4.1, Bio-Rad Laboratories, Inc., Hercules, CA, USA).

Statistical analysis. Data are expressed as the means \pm standard deviation from experiments performed in triplicate. Multi-group comparisons of the means were carried out by one-way analysis of variance test with post hoc contrasts by Student-Newman-Keuls test. All statistical analyses were performed using SPSS software (SPSS Statistics 20.0; IMB Corp, Armonk, NY, USA). P-values were two-tailed; $\mathrm{P}<0.05$ was considered to indicate a statistically significant difference.

\section{Results}

Inhibition of steviol on the viability of U2OS cells. For comparison, two common chemotherapy agents ADM ( $\mathrm{LD}_{50}$, $570 \mathrm{mg} / \mathrm{kg}$, oral, mouse) and 5-FU ( $\mathrm{LD}_{50}, 115 \mathrm{mg} / \mathrm{kg}$, oral, mouse) were used as positive contrasts in this experiment. Fig. 1 indicated that steviol presented similar inhibition rates as 5-FU, but weaker compared with ADM; they all inhibited $\mathrm{U} 2 \mathrm{OS}$ cell viability in time- and dose-dependent manners. The $\mathrm{IC}_{50}$ values for steviol, ADM and 5-FU were 200, 1.2 and $250 \mu \mathrm{g} / \mathrm{ml}$, respectively, in U2OS cells after $24 \mathrm{~h}$. Moreover, as demonstrated in Fig. 2, a progressive inhibition of colony formation was observed with increasing steviol concentrations. Furthermore, microscopic observations of the cell morphology and numbers suggested cell apoptosis, which was examined in subsequent experiments.

Steviol causes G1 phase arrest and apoptosis in U2OS cells. Flow cytometry analysis was performed to determine the cell cycle distribution and population of dead cells in steviol-treated U2OS cells. Exposure to steviol resulted in a marked increase in the percentages of U2OS cells in G1 phase and decrease of the S and G2 populations in the cell cycle (Fig. 3; Table I). Therefore, steviol may cause G1 arrest in cell cycle of U2OS cells. The mechanism will be discussed subsequently.

To further identify cell apoptosis, Hoechst staining (Fig. 4A) and JC-1 staining (Fig. 4B) were employed, followed by Annexin V-FITC/PI double-labeled flow cytometry (Fig. 4C and D). As steviol concentration increased, the green fluorescence intensity increased (Fig. 4B). All results indicate a concentration-dependent effect on cell apoptosis. The total apoptosis ratio increased from 0.04 to $24.10 \%$ with the increasing concentration of steviol up to $200 \mu \mathrm{g} / \mathrm{ml}$ in $48 \mathrm{~h}$ (Fig. 4C). These results suggest that steviol inhibits the viability of U2OS cell through cell cycle arrest at the G1 phase and by stimulating apoptosis.

Apoptotic pathway. Firstly, to investigate the mechanism of steviol-mediated G1 arrest, the levels of G1 regulation-associated proteins p21, p53, Cyclin D1, Cyclin E, and CDK2 were assessed. As demonstrated in Fig. 5, the expression of p21, p53, Cyclin E and CDK2 was upregulated, whereas Cyclin D1 was downregulated, and all were concentration dependent.

Subsequently, the apoptosis-associated proteins Bcl-2, Bax, Caspase 3 and Survivin in the steviol treated U2OS cells were detected using western blotting.

Fig. 6 reveals that the expression level of Bax was increased whereas Bcl-2, Caspase 3 and Survivin were decreased in a concentration-dependent manner. This indicates that the ratio of Bax/Bcl-2 was upregulated with increasing concentrations of steviol, suggesting an activation of mitochondrial apoptotic pathway.

\section{Discussion}

As aforementioned, steviol has not been studied intensively as a potential anticancer agent, nor its mechanism of inhibition in cancer cells. Boonkaewwan and Burodom (22) indicated that steviol decreased cell viability at concentrations of 200-800 $\mu \mathrm{mol} / 1$, for example, 63.7-254.8 $\mu \mathrm{g} / \mathrm{ml}$ in T84, Caco-2 and HT29 cells; the $\mathrm{IC}_{50}$ values were $400-800 \mu \mathrm{mol} / 1$, similar to the results demonstrated in the present study. The steviol used by Boonkaewwan and Burodom (22) was $90 \%$ pure, obtained from the oxidation of stevioside (23).

However, the effects of other drugs on the cell cycle in U2OS cells have been studied: Riccardin D (RD), a liverwort-derived product was identified to cause arrest of U2OS cells in G1 phase, while p53 was not required in the apoptosis; caspase-independent mechanisms were observed to be involved in RD-mediated cell death (22). An additional liverwort-derived product dihydroptychantol A induced G2/M-phase cell cycle 


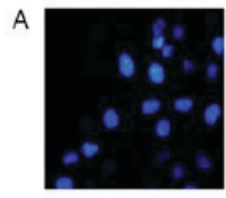

Control

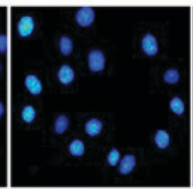

$50 \mu \mathrm{g} / \mathrm{ml}$

C

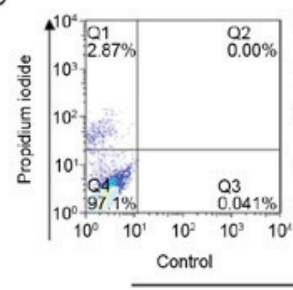

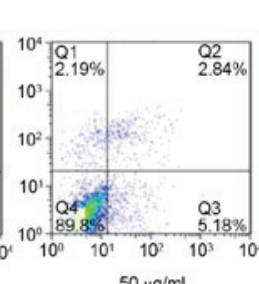

$50 \mu \mathrm{g} / \mathrm{ml}$

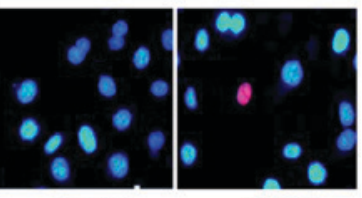

$200 \mu \mathrm{g} / \mathrm{ml}$

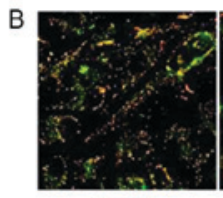

Control

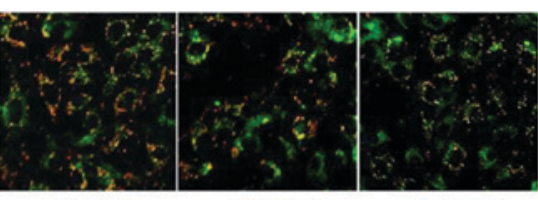

$50 \mu \mathrm{g} / \mathrm{ml}$
$100 \mu \mathrm{g} / \mathrm{ml}$

$200 \mu \mathrm{g} / \mathrm{ml}$

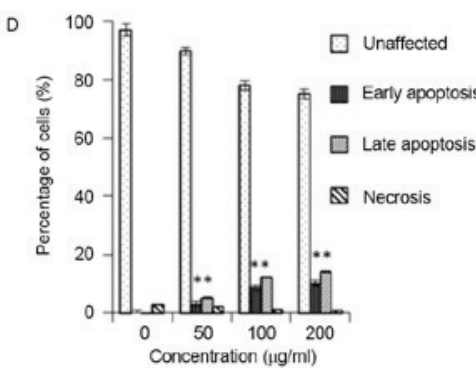

Figure 4. Steviol induced apoptosis of U2OS cells. (A) Photomicrographs of Hoechst 33342 staining. (B) Concentration-dependent effect of steviol on mitochondrial membrane potential of U2OS cells. As steviol concentration increased, the green fluorescence intensity increased. (C) U2OS cells were treated with steviol for $48 \mathrm{~h}$ and stained with Annexin V-propidium iodide. (D) The percentage of apoptotic cells was measured by flow cytometry analysis * $\mathrm{P}<0.05$ and ${ }^{* *} \mathrm{P}<0.01$ vs. untreated cells. FITC, fluorescein isothiocyanate.

A

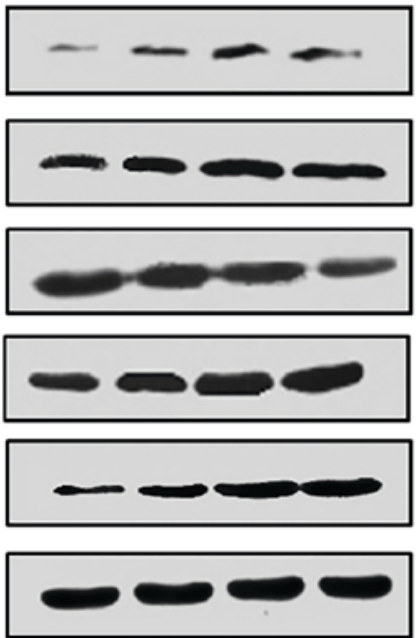

$\mathrm{p} 21$

\section{p53}

Cyclin D1

Cyclin E

CDK2

$\beta$-Actin
B

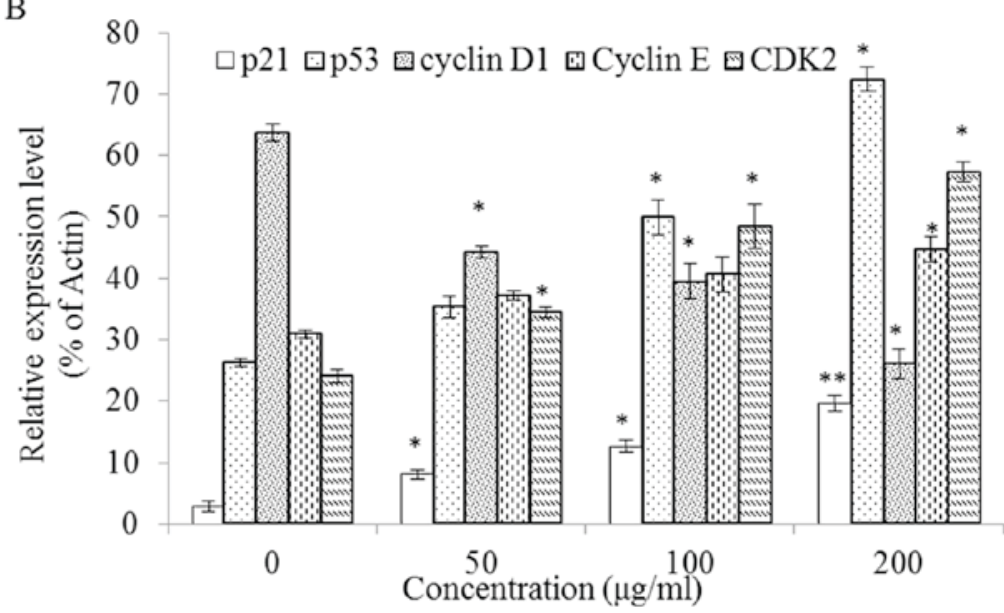

Figure 5. Expression of cell cycle-associated proteins regulated by steviol. (A) p21, p53, Cyclin D1, Cyclin E, CDK2. (B) Relative expression levels of cell cycle-associated proteins, calculated based on densitometric analysis. $\beta$-actin was used as an internal control. "P<0.05 and ${ }^{* *} \mathrm{P}<0.01$ vs. untreated cells. p21, cyclin-dependent kinase inhibitor 1; p53, tumor protein 53; CDK2, cyclin-dependent kinase 2.

A
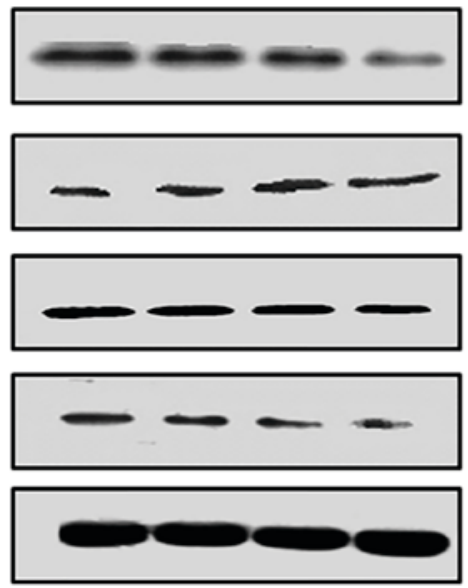

Bcl-2

Bax

Caspase 3

Survivin

$\beta$-Actin

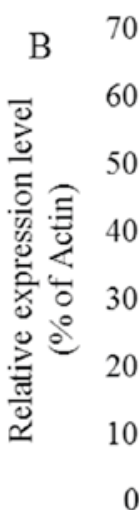

0

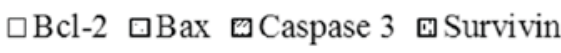

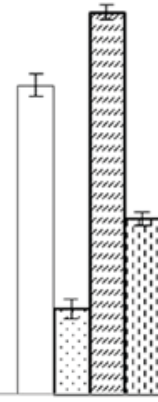

0

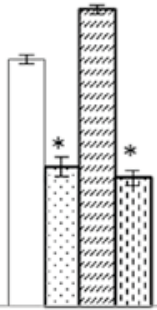

50

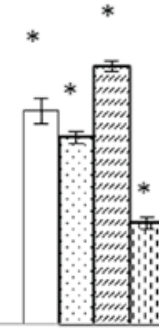

100

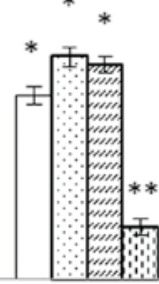

200

Concentration $(\mu \mathrm{g} / \mathrm{ml})$

Figure 6. Expression of cell apoptosis-associated proteins regulated by steviol. (A) Bcl-2, Bax, Caspase 3, Survivin; (B) Relative expression levels of the apoptosis-associated proteins, calculated using densitometric analysis. $\beta$-actin was used as an internal control. " $\mathrm{P}<0.05$ and ${ }^{* *} \mathrm{P}<0.01$ vs. untreated cells. Bcl-2, B-cell lymphoma 2; Bax, Bcl-associated X protein. 
arrest and apoptosis in U2OS cells by decreasing the expression of cyclin B1 (28). Cappadone et al (29) revealed that NSC743420, an indole derivative, induced a cytostatic and differentiating effect in U2OS cells, characterized by the cell cycle arrest in G0/G1 phase and increased alkaline phosphatase activity. In the present study, as indicated Figs. 3-6, the underlying mechanism of cell cycle regulation induced by steviol, and the G1 phase-associated proteins were identified along with the apoptosis-associated proteins.

Among these proteins, p21 is a cyclin-dependent kinase inhibitors. As it well-known, cyclin D1 is a regulatory subunit of cyclin-dependent kinases CDK4 and CDK6, dimerized with $\mathrm{CDK} 4 / 6$ to regulate the G1/S phase transition and entry into the S-phase. Cyclin D1-CDK4 also enables the activation of the cyclin E-CDK2 complex by sequestering the CDK interacting protein/kinase inhibitory protein family protein p21 (30). Therefore, all regulations presented in Fig. 5 are coincident with Fig. 3. In conclusion, steviol induced G1 arrest of U2OS cells by suppressing the expression of Cyclin D1 and upregulating the expression of p21, p53, Cyclin E, and CDK2.

The Bcl-2 family proteins serve crucial roles in controlling the intrinsic (mitochondrial) apoptotic pathway, which is one of the major mechanisms that induces apoptotic cell death (31). It has been suggested that an alteration in the balance between anti-apoptotic Bcl-2 and pro-apoptotic Bax is a critical factor in regulation of the susceptibility of cells to apoptosis (32).

Taken together, the results revealed that steviol induced the mitochondrial apoptotic pathway in U2OS cells, and that a Survivin and Caspase 3-independent mechanism was involved.

In conclusion, the present study indicates that steviol possesses an anticancer activity in human osteosarcoma U2OS cell line, similar to 5-FU or AMD. Steviol inhibits the proliferation of U2OS by inducing G1 cell cycle arrest and mitochondrial apoptosis, as demonstrated by the upregulation of the Bax/Bcl-2 ratio, activation of p21, p53 and CDK2; a Survivin and Caspase 3-independent mechanism may also be involved. These data may suggest the steviol could be a potential anticancer drug as a natural sweetener metabolite. However, additional studies are required to verify the in vivo effects of steviol in osteosarcoma.

\section{Acknowledgements}

The present study was supported by the National Natural Science Foundation of China (grant no. 31772017; 31371837) and the Project of Outstanding Scientific \& Technological Innovation Group of Jiangsu Province.

\section{References}

1. Renwick AG and Tarka SM: Microbial hydrolysis of steviol glycosides. Food Chem Toxicol 46 (Suppl 7): S70-S74, 2008.

2. Purkayastha S, Pugh G Jr, Lynch B, Roberts A, Kwok D and Tarka SM Jr: In vitro metabolism of rebaudioside B, D, and M under anaerobic conditions: Comparison with rebaudioside A. Regul Toxicol Pharmacol 68: 259-268, 2014.

3. Toskulkac C, Chaturat L, Temcharoen P and Glinsukon T: Acute toxicity of stevioside, a natural sweetener, and its metabolite, steviol, in several animal species. Drug Chem Toxicol 20: 31-44, 1997.

4. Moons N, De Borggraeve W and Dehaen W: Stevioside and steviol as starting materials in organic synthesis. Curr Organic Chem 16: 1986-1995, 2012
5. EFSA Panel on Food Additives and Nutrient Sources (ANS): Scientific Opinion on safety of steviol glycosides for the proposed uses as a food additive. EFSA Journal 8: 1537, 2010.

6. Ge Y, Wang Y, Pang L, Zhang L, Zhai Y and Zhou H: Proliferation, apoptosis, and invasion effects of mistletoe alkali on human osteosarcoma U2OS in vitro. Int Surg: April 25, 2016 (Epub ahead of print).

7. Luetke A, Meyers PA, Lewis I and Juergens H: Osteosarcoma treatment-where do we stand? A state of the art review. Cancer Treat Rev 40: 523-532, 2014.

8. Zhang J, Zhu X, Li H, Li B, Sun L, Xie T, Zhu T, Zhou H and Ye Z: Piperine inhibits proliferation of human osteosarcoma cells via G2/M phase arrest and metastasis by suppressing MMP-2/-9 expression. Int Immunopharmacol 24: 50-58, 2015.

9. Ottaviani G and Jaffe N: The Epidemiology of Osteosarcoma. In: Pediatric and Adolescent Osteosarcoma. Jaffe N, Bruland OS and Bielack S (eds.) Springer US, pp3-13, 2010.

10. Bielack SS, Kempf-Bielack B, Delling G, Exner GU, Flege S, Helmke K, Kotz R, Salzer-Kuntschik M, Werner M, Winkelmann W, et al: Prognostic factors in high-grade osteosarcoma of the extremities or trunk: an analysis of 1,702 patients treated on neoadjuvant cooperative osteosarcoma study group protocols. J Clin Oncol 20: 776-790, 2002.

11. Rejniak KA, Lloyd MC, Reed DR and Bui MM: Diagnostic assessment of osteosarcoma chemoresistance based on Virtual Clinical Trials. Med Hypotheses 85: 348-354, 2015.

12. Luetke A, Meyers PA, Lewis I and Juergens H: Osteosarcoma treatment-Where do we stand? A state of the art review. Cancer Treat Rev 40: 523-532, 2014.

13. Ta HT, Dass CR, Choong PF and Dunstan DE: Osteosarcoma treatment: State of the art. Cancer Metastasis Rev 28: 247-263, 2009.

14. Hattinger CM, Pasello M, Ferrari S, Picci P and Serra M: Emerging drugs for high-grade osteosarcoma. Expert Opin Emerg Drugs 15: 615-634, 2010.

15. Janeway KA and Grier HE: Sequelae of osteosarcoma medical therapy: A review of rare acute toxicities and late effects. Lancet Oncol 11: 670-678, 2010.

16. Muñoz A, Alfaro J, Pardo N, García-Miguel P, Quintero V, Gros L, Melero C, Antuña MJ, Ocete G, de Las Heras J, et al: Long-term results of the Spanish Protocol SO-95 for the treatment of non-metastatic high-grade osteosarcoma of the extremities in children. Clin Transl Oncol 11: 387-392, 2009.

17. Zhao S, Lu N, Chai Y and Yu X: Rapamycin inhibits tumor growth of human osteosarcomas. J Buon 20: 588-594, 2015.

18. Lu M, Huang W, Bao N, Zhou G and Zhao J: The flavonoid ampelopsin inhibited cell growth and induced apoptosis and G0/G1 arrest in human osteosarcoma MG-63 cells in vitro. Pharmazie 70: 388-393, 2015.

19. Lee DH, Qi J, Bradner JE, Said JW, Doan NB, Forscher C, Yang H and Koeffler HP: Synergistic effect of JQ1 and rapamycin for treatment of human osteosarcoma. Int J Cancer 136: 2055-2064, 2015.

20. Maugg D, Rothenaigner I, Schorpp K, Potukuchi HK, Korsching E, Baumhoer D, Hadian K, Smida J and Nathrath M: New small molecules targeting apoptosis and cell viability in osteosarcoma. PLoS One 10: e0129058, 2015.

21. Meng ZJ, Wu N, Liu Y, Shu KJ, Zou X, Zhang RX, Pi CJ, He BC, Ke ZY, Chen L, et al: Evodiamine inhibits the proliferation of human osteosarcoma cells by blocking PI3K/Akt signaling. Oncol Rep 34: 1388-1396, 2015.

22. Wang Y, Ji Y, Hu Z, Jiang H, Zhu F, Yuan H and Lou H: Riccardin D induces cell death by activation of apoptosis and autophagy in osteosarcoma cells. Toxicol in Vitro 27: 1928-1936, 2013.

23. Boonkaewwan C, Ao M, Toskulkao C and Rao MC: Specific immunomodulatory and secretory activities of stevioside and steviol in intestinal cells. J Agric Food Chem 56: 3777-3784, 2008.

24. Yuajit C, Muanprasat C, Gallagher AR, Fedeles SV, Kittayaruksakul S, Homvisasevongsa S, Somlo S and Chatsudthipong V: Steviol retards renal cyst growth through reduction of CFTR expression and inhibition of epithelial cell proliferation in a mouse model of polycystic kidney disease. Biochem Pharmacol 88: 412-421, 2014.

25. Takasaki M, Konoshima T, Kozuka M, Tokuda H, Takayasu J, Nishino H, Miyakoshi M, Mizutani K and Lee KH: Cancer preventive agents. Part 8: Chemopreventive effects of stevioside and related compounds. Bioorg Med Chem 17: 600-605, 2009. 
26. Shen J, Park HS, Xia YM, Kim GS and Cui SW: The polysaccharides from fermented Ganoderma lucidum mycelia induced miRNAs regulation in suppressed HepG2 cells. Carbohydr Polym 103: 319-324, 2014.

27. Plumb JA: Cell sensitivity assays: The MTT assay. In: Cancer Cell Culture Springer, pp165-169, 2004

28. Li X, Wu WK, Sun B, Cui M, Liu S, Gao J and Lou H: Dihydroptychantol A, a macrocyclic bisbibenzyl derivative, induces autophagy and following apoptosis associated with p53 pathway in human osteosarcoma U2OS cells. Toxicol Appl Pharmacol 251: 146-154, 2011.

29. Cappadone C, Stefanelli C, Malucelli E, Zini M, Onofrillo C, Locatelli A, Rambaldi M, Sargenti A, Merolle L, Farruggia G, Graziadio A, et al: p53-dependent and p53-independent anticancer activity of a new indole derivative in human osteosarcoma cells. Biochem Biophys Res Commun 467: 348-353, 2015.
30. Diehl JA: Cycling to cancer with cyclin D1. Cancer Biol Ther 1: 226-231, 2002.

31. Martin S, Reutelingsperger C, McGahon AJ, Rader JA, van Schie RC, LaFace DM and Green DR: Early redistribution of plasma membrane phosphatidylserine is a general feature of apoptosis regardless of the initiating stimulus: Inhibition by overexpression of Bcl-2 and Abl. J Exp Med 182: 1545-1556, 1995.

32. Zinkel S, Gross A and Yang E: BCL2 family in DNA damage and cell cycle control. Cell Death Differ 13: 1351-1359, 2006. 